\title{
ALLELOPATHIC EFFECT OF Cinnamomum verum ON EMERGENCE AND SEEDLING GROWTH OF RADISH
}

Rizwan Maqbool ${ }^{1}$, Bilal Ahmad Khan ${ }^{2 *}$, Muhammad Ather Nadeem ${ }^{2}$, Sumbal Parvez ${ }^{3}$, Muhammad Mohsin Amin ${ }^{2}$, Jamshahid Qamar ${ }^{2}$, Azhar Hassan ${ }^{1}$, Muhammd Alam Elahi ${ }^{1}$, Jamshed Haider ${ }^{1}$, Muhammad Irfan ${ }^{4}$ and Memuna Ghafoor Shahid ${ }^{5}$

DOI: https://doi.org/10.28941/pjwsr.v27i4.975

\begin{abstract}
Crop plants release biochemicals into surrounding environment that help in obtaining maximum yield of crop by acting as bioherbicide at high concentration and plant growth hormone at low concentration. Therefore, this study was planned at the Department of Agronomy in Weed Science Laboratory, University of Agriculture Faisalabad during Winter season of 2018 to evaluate the hermetic effects of Cinnamomum verum (Dalchini) on vegetable crop radish (Raphanus sativus L.) and determination and quantification phenolic compound present in aqueous extract of bark of $C$. verum. The experiments were laid out under completely randomized design with three replications. The aqueous extracts of $C$. verum was used on radish seeds at different concentrations $(2.5 \%, 5 \%, 10 \%, 20 \%, 40 \%$ and $80 \%)$. Data regarding seed germination and seedling growth (shoot length, root length, shoot fresh weight, root dry weigh) of radish were recorded following standard procedures. Results of our study revealed that the higher concentration acted as bioherbicide and exhibited inhibitory effects on $R$. sativus while the low concentration it showed hermetic effect and promoted the seedling growth. Among different phenolic compound (syringic acid, p-crumeic, ferulic acid, quercetion and gallic acid) were determined in aqueous extract of bark of $C$. verum, maximum quercetion (12.3\%) and minimum syringic acid $(0.60 \%)$. It was concluded from this study that aqueous extract of $C$. verum can be used as bioherbicide at higher concentration to control weed while at low concentration as plant growth regulator.
\end{abstract}

Keywords: Allelopathy, Raphanus sativus, Lower concentration, Germination and Seedling growth.

Citation: Maqbool, R.; B.A. Khan; M.A. Nadeem; S. Parvez; M.M. Amin; J. Qamar; A. Hassan; M.A. Elahi; J. Haider; M. Irfan; and M.G. Shahid 2021. Allelopathic Effect of Cinnamomum verum on Emergence and Seedling Growth of Radish. Pak. J. Weed Sci. Res., 27(4): 485-494.

\footnotetext{
${ }^{1}$ Department of Agronomy, University of Agriculture, Faisalabad-38000, Pakistan.

${ }^{2}$ Department of Agronomy, College of Agriculture, University of Sargodha-40100 Pakistan.

${ }^{3}$ Department of Botany, University of Agriculture, Faisalabad-38000, Pakistan.

${ }^{4}$ Scientific Officer, plant Breading \& Genetics Group, Soil Salinity Research Institute, Pindi Bhattian, Punjab, Pakistan.

${ }^{5}$ Department of Botany, GC University, Lahore 54000, Pakistan

Corresponding author's emaol: bilalahmadkhan678@gmail.com
} 


\section{Introduction}

Crop plants release chemicals into surrounding environment that have ability to either suppress or promote the growth of target crop plant or weed. This phenomenon is very important in biological control of weeds by releasing secondary compounds. These secondary metabolic compounds such as tannins, alkaloids, glycosides, cyanogen, sesquiterpenes, phenolic acids, flavonoids, and many others having allelopathic activity (King and Ambika, 2002; Javaid et al., 2010a). Weeds are unwanted plants in main crop that pose aggressive, competitive, troublesome, and multifaceted effect on crops and reduce the yields of crop (Nadeem et al., 2020a). Herbicides are chemicals compounds that are used for controlling weeds, but they cause several environmental risks. Therefore, finding the harmless and potent systems for controlling weeds was of main attention for maintaining the agricultural yields (Hazrati et al., 2017). Usual product escape out from the remains of medicinal plant might assist to decrease the usage of artificial made herbicides for weed management (Sodaeizadeh et al., 2010; Javaid et al., 2010b).

The biochemical compounds manufactured in plant as secondary compounds have been nonsignificant role in plants but act as defensing agent in plant. Phenolic as well as terpenoids usually characterized as allelochemical display chemical diversity and number of metabolic and physiological biochemical process. The phenomena of allelopathy in crop plant may increase the yield as well as growth of allelopathic plant via suppressing the weed growth, with the usage of allelochemicals as natural herbicides as well as growth promoter (Maqbool et al., 2021a; Javaid, 2010). These allelochemical can pass into the atmosphere via different ways such as leakage volatilization, root exudations, seed coat exudations by decaying of diverse part of plant (Rice et al., 2007).

A number of researchers, such as Nadeem et al., 2021a; Maqbool et al., 2021b; Nelson, 1996 and Rice et al., 2007 had documented the interference effects of some plants on other crops, prominent of which the inhibition of germination (Djurdjevic et al., 2004), reduction in the growth lengths of plumule and radicle (Tobe et al., 2000), retardation of seedling growth (Bhatt and Todoria, 1990) and poor seedling survival (Smitt, 1990). Allelochemicals inhibits seed germination by blocking of nutrient reserve and cell division thereby caused significant reduction in the growth of plumule and radicle of many crops (Tobe et al., 2000). Allelochemicals formed in plant might be escaped out from the tissue of plant and different part of plant into soil atmosphere and environment through leaching exudation of root, decaying of plant remains and volatilization and effect the growth of neighboring plant (Golisz et al., 2007).

Under stressful condition the concentration of allelochemical in plants increases while under normal conduction remain stable. The main purpose of allelochemical in plants is to protect the plant form unpredictable environmental stress such as drought, mineral deficiency, temperature, herbivores grazing, water deficiency, etc. Therefore, stress simply referred as any shortage or excess supply of plant essential compounds that hinder to complete the life cycle and retard the usual growth and development of plant. The aqueous extract of different part of allelopathic plant such as roots, stem, leaves and seeds have been used valuable possessions to manage the weed through natural ways (Jamil et al., 2009; Javaid et al., 2020). Ethanolic or methanolic aqueous extracts were used as possible herbicide in mixtures (Cheema et al., 2012). By these methods allelochemicals may be able to manage weeds via weaken weed-plant competition and enhance the crop growth and yield (Murrell et al., 2011).

Water extract application of allelopathy at lower concentrations stimulates development and growth of diverse crops (Nadeem et al., 2020a; Nadeem et al., 2020b). Cinnamomum verum are a normal-sized tree (10 to 15 $\mathrm{m})$ native to Sri Lanka and tropicalAsia; the cultivated in the Southern India due to strong scented leaf; bark and the aromatic oils take out from 
through steam purification, barks of Cinnamomum verum used in experiment to check the allelopathic potential, plane, light brown color and up to $10 \mathrm{~mm}$ thickness; the foremost compound gain from the bark of C. verum are Eugenol, Cinnamaldehyde, phenolic compounds such as chlorogenic acid, vanillic acid, caffeic acid and Linalool (Kubeczka, 2002). The presence of phenolic in bark exhibit inhibitor possession on the plant germination. Based on the previous idea, the present research was conducted to study the allelopathic effect of $C$. verum on vegetable characteristics of radish crop.

\section{Materials and Methods}

\section{Collection $C$. verumplant parts}

To make aqueous extract $C$. verum (bark) plant parts were purchased from Ayub Agricultural Research Institute of Faisalabad (AARI).

\section{Preparation of $C$. verum parts} aqueous extracts

Plant parts such as bark of $C$. verum were chopped in 2 to $3 \mathrm{~cm}$ parts. Then the chopped bark was soaked in distilled water at 1:80 ratio for 2 days (about 48 hours). The aqueous extracts of chopped samples were filtered through filter paper. The concentered solution was then diluted with distilled water ( $/ \mathrm{v} \%)$ to make different concentrations of solution. Almost seven concentrations $(0 \%, 2.5 \%, 5 \%, 10 \%$, $20 \%, 40 \%$ and $80 \%$ ) were prepared to study the allelopathic activity of the extract. Seven concentrations 0, 2.5, 5, $10,20,40$, and $80 \%$ were prepared by taking extract into $250 \mathrm{ml}$ flask and adding $2.5,5,10,20,40-$ and $80-\mathrm{ml}$ stock solution of $C$. verumm; whereas controlled solution contained only 250 $\mathrm{ml}$ distilled water.

Each dilution of each extract placed in separate tagged bottles by name of each dilution and plant to avoid confusions during utilization in next procedures. The experiment was conducted in $9 \mathrm{~cm}$ petri dishes lined with filter no.10-filter paper.

To estimate the allelopathic effect, $0 \%, 0.25 \%, 0.5 \%, 1 \%, 2 \%, 4 \%$ and $8 \%$ concentrations of each plant part of $C$. verum were applied on wild pea seeds separately. Twenty seeds of $O$. punctate were placed in each Petri dishes containing filter paper. A $7 \mathrm{~mL}$ of all $C$. verum extracts dilutions of each part (leaves, stem, flower and fruit) was added in respective petri dishes having 3 replications of each dilution. One treatment was kept as control and moist with distilled water. To minimize the excess of evaporation petri dishes were covered and rapped with parafilm. The petri dishes were kept at the temperature of $30{ }^{\circ} \mathrm{C}$ and were again moistened with $3 \mathrm{~mL}$ after one week. The data regarding emergence of the seeds were noted every day for 14 days. After the 14 days, the germinated seedlings of wild pea were taken for different parameters like shoot length, root length, fresh and dry weight. Fresh weight was recorded instantly after harvesting while the dry weight of seedling was observed after oven drying for two days at $60{ }^{\circ} \mathrm{C}$.

\section{Experimental site}

Laboratory experiments were conducted at weeds Science Laboratory, Department of Agronomy, University of Agriculture, Faisalabad to check the allelopathic effects of $C$. verum on wild pea (weed) and radish (crop plant).

\section{Laboratory Experiment}

This study was carried out using water as extracting medium because allelochemicals are often water soluble and released into the environment through root exudations, leaching by dews and rains or decaying of plant tissue (Turk and Tawaha, 2003). Ten vigorous seeds of wild pea were placed in Petri dishes and $C$. verum prepared aqueous solution were functionally applied at every specific petri dish purified water also cast-off like control treatment. After applying solution, Petri dishes were wrapped with paper tape and placed at room temperature. Petri dishes would keep moisture by applying solution whenever needed. Percentage of germination, mean germination, root length, shoot length and fresh weight of root and shoot were taken afterward the $12^{\text {th }}$ day. Shoot length and root length were measured with measuring scale and fresh weight on weight machine. The diluted extracts of $C$. Verum $(0 \%$, $2.5 \%, 5 \%, 10 \%, 20 \%, 40 \%, 80 \%$ ) were applied separately on wild pea.

\section{Data collection}




\section{Mean emergence time of $P$. sativum(day) \\ Ellis and Reborts (1981) equation} were used to examine the mean emergence time (MET).

$$
M E T=\sum \frac{(D n)}{\sum n}
$$

\section{Emergence index of $\boldsymbol{P}$. sativum}

By using formula of Association of the Official seed Analysis (1990) we recorded the emergence index

$G I=\frac{\text { No. of emerged seeds }}{\text { Days of first count }}+---+\frac{\text { No. of emerged seeds }}{\text { Days of final count }}$ Emergence percentage of $\boldsymbol{P}$. sativum (\%)

Number of emerged seeds were counted daily according to the method of the association of Official Seed Analysis (1990) and converted into emergence percentage by the following formula.

Emergence $(\%)=\frac{\text { No. of emerged seeds }}{\text { Total seeds }} \times 100$

Time taken to $\mathbf{5 0 \%}$ emergence of $P$. sativum (day)

The time to the $50 \%$ emergence $\left(E_{50}\right)$ was recorded by using the formula purposed by Coolbear et al. (1984)

$E$ 固50 $=t i+\left[\frac{\frac{N}{2}-n i}{n j-n i}\right](t j-t i)$

\section{Growth attributes of $\boldsymbol{P}$. sativum}

All seedlings from each petri dish were separated 14 days after emergence. After that both shoot length and root length were calculated by using meter rod from base level to top of the plants. Seedlings fresh weight was examined by separating seedlings from petri dish and measuring by using digital weight balance.

\section{Phenolic contents}

Phenolic contents were determined by using HPLC (Gradient, Reverse Phase made from shimadzu japan detector SPD-10 Av Pump LC-10AT). Made the $(w / v)$ solution at 1.10 ratio (10 g powdered of $C$. verum and $A$. officanlis and $100 \mathrm{~mL}$ methanol) Then wrapped the beaker with aluminum foil and placed for 10 days. After 10 days the material was semidried. $5 \mathrm{mg}$ weight with electrical balance taken out for phenolic analysis. In $A$. officanlis quercetin, pcoumaric, ferulic acid, gallic acid and syringic acid were detected.

\section{Statistical analysis}

Statistics software (version,

8.1Statistix, Tallahassee, FL, USA) was used to analyses the collected data and least significant difference test (LSD) was used to compare the means of treatment at probability level of $5 \%$.

\section{Results and Discussions}

Allelopathic effect of $C$. verum on radish seeds emergence

\section{Time to $\mathbf{5 0} \%$ germination ( $\mathrm{T}_{50}$ )}

The aqueous extract of $C$. verum had significant effect on $T_{50}$ of $R$. sativus (Table 1). Maximum $\mathrm{T}_{50}$ (5.91 days) of radish seeds was observed at $\mathrm{T}_{3}(5 \%)$ concentration. Minimum $\mathrm{T}_{50}$ (4.03 days) of radish seeds was observed at $\mathrm{T}_{5}$ $(20 \%) . \mathrm{T}_{7}(80 \%)$ concentration were statistically non-significant with $\mathrm{T}_{6}$ $(40 \%)$ concentration which were statistically at par with $\mathrm{T}_{5}(20 \%), \mathrm{T}_{4}$ $(10 \%)$ and $T_{2}(2.5 \%)$ concertation. $T_{3}$ (5\%) concentration statistically significant with $\mathrm{T}_{1}(0 \%)$ concentration. The time taken to $50 \%$ germination of radish seed was increased by (55\%) at $\mathrm{T}_{7}(80 \%)$ concentration as compared to control treatment $\mathrm{T}_{1}(0 \%)$. The previous results revealed that extract of different plant parts of $M$. oleifera affected the rate of germination of $V$. radiata in laboratory condition. The degrees of inhibitory effects of different plant parts on germination were different. Same result reported Cheema et al. (1997) that sorghum water extract inhibited germination of certain weed species. sorghum extract could significantly decrease germination percentage in some crops.

\section{Germination index (GI)}

The effect of $C$. verum bark aqueous extract had significant effect on germination time of $R$. sativus (Table 1 ). Maximum germination (8.05) of radish seeds was observed at $\mathrm{T}_{3} \quad(5 \%)$ concentration. while minimum germination (4.93) of radish seeds was observed at $\mathrm{T}_{7} \quad(80 \%) . \mathrm{T}_{7} \quad(80 \%)$ concentration were statistically nonsignificant with $\mathrm{T}_{6}(40 \%)$ concentration which was statistically at par with $\mathrm{T}_{5}$ (20\%) concertation. $\mathrm{T}_{3} \quad(5 \%)$ concentration statistically significantly with $\mathrm{T}_{1}(0 \%)$ concentration. The time taken to $50 \%$ germination of radish seed was increased by $(55 \%)$ at $\mathrm{T}_{7}(80 \%)$ 
concentration as compared to controlled $\mathrm{T}_{1}(0 \%)$. The result was corresponding to Costa and Zimmermann (1988), who stated that according to environmental conditions, some production components may increase or decrease.

\section{Mean germination time (MGT)}

The effect of Cinnamomum verum bark aqueous extract had significant effect on mean germination time of Raphanus sativus (Table 1 ). Maximum MGT (6.44 day) of radish seeds were observed at $T_{1} \quad(0 \%)$ concentration. Whereas MGT (4.82 days) of radish seeds was observed at $\mathrm{T}_{5}$ $(20 \%)$ concentration of extract. $\mathrm{T}_{7}$ $(80 \%)$ concentration were statistically non-significant with $\mathrm{T}_{6} \quad(40 \%)$ concentration which was statistically at par with $\mathrm{T}_{5}(20 \%), \mathrm{T}_{4} \quad(10 \%)$ concertation. $\mathrm{T}_{3} \quad(5 \%)$ concentration statistically significant when compared with $\mathrm{T}_{1}(0 \%)$. The obtained results supported by previous studies that concentrations of allelochemicals at small concentrations of allelochemicals might stimulate the development and growth while increase concentrations suppress or inhibiting the growth and germination of target plant (Hazrati et al., 2017; Tigre et al., 2012).

\section{Germination percentage (GP)}

The bark extract of $C$. verum had significant effect on germination percentage of Pisum sativum sub species elatius (Table 1). Maximum percentage of germination $(96.6 \%)$ of wild pea seeds was observed at $\mathrm{T}_{1} \quad(0 \%)$ concentration of extract. whereas minimum percentage of germination $(70.0 \%)$ of wild pea seed was observed at $\mathrm{T}_{7}(80 \%)$ and $\mathrm{T}_{6}(40 \%)$ concentration of extract. $\mathrm{T}_{7}(80 \%)$ concentration showed statistically significant relationship with $\mathrm{T}_{1}(0 \%)$ concentration. $\mathrm{T}_{7}(80 \%)$ concentration showed nonsignificant relationship with $\mathrm{T}_{6}(40 \%)$ concentration. The germination percentage of wild pea seed was significantly decreased $27 \%$ at $\mathrm{T}_{7}(80 \%)$ concentration as compared to controlled $\mathrm{T}_{1}(0 \%)$. Same result reported Cheema et al. (1997) that sorghum water extracts inhibited germination of certain weed species. Sorghum extract could significantly decrease germination percentage in some crops.

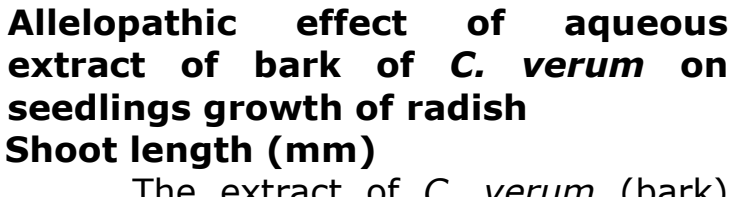

The extract of $C$. verum (bark) had significant effect on shoot length of radish as described in Table 2. Maximum shoot length $(93.8 \mathrm{~mm})$ of radish seedling was observed at $\mathrm{T}_{7}(80 \%)$ concentration. Minimum shoot length $(61.6 \mathrm{~mm})$ of radish were observed at controlled $\mathrm{T}_{1}(0 \%)$ concentration. $\mathrm{T}_{2}$ $(2.5 \%)$ concertation showed nonsignificant relationship with $\mathrm{T}_{6}(40 \%)$ concertation which was statically at par with $\mathrm{T}_{3} \quad(5 \%)$ and $\mathrm{T}_{5} \quad(10 \%)$ concentration. $\mathrm{T}_{7}(80 \%)$ concentration showed significant relationship with $\mathrm{T}_{1}$ $(0 \%)$ concentration. The maximum shoot length of radish significantly increased (52\%) at $\mathrm{T}_{7}$ (80\%) concentration as compared to control $\mathrm{T}_{1}$ $(0 \%)$ concentration. Increased in concentration not dramatically reduce the shoot length of radish. Increase in shoot length of radish over control by application of bark extract of $C$. verum showed that stimulatory allelochemicals in these extracts might be the reason. The obtained result was not according to Reigosa et al. (2006) that Cinnamon abstract repressed the fungus growth yet 2.0 and $2.5 \%$ have the most effective because these concentrations were not permit the disease-causing agent to grow and showed $100 \%$ inhibition in bio-mass production. Besides these also proposed that increase concentrations might badly influence the development of the plant. But the results are supported by Rice, (1984) analysis that difference in extract concentration might be shown different results, (both inhibitory and stimulating results).

\section{Root length ( $\mathrm{mm}$ )}

The extract of $C$. verum (bark) had significant effect on $R$. sativus $L$. as described in Table 2. The extract brought about considerable inhibition in the root length of radish seedling. Degree of inhibition increased with increasing the concentrations of the extracts. This tends to suggest that the effect of the extract is concentration dependent. The maximum root length $(129.3 \mathrm{~mm})$ was observed at control $\mathrm{T}_{1}$ 
$(0 \%)$ concentration. Minimum reduction in root length $(21.7 \mathrm{~mm})$ was observed at $\mathrm{T}_{7}(80 \%)$ concentration. At the highest extract concentration all aqueous extracts significantly, reduced root length as to compared controlled treatment. $\mathrm{T}_{7} \quad(80 \%)$ concentration statistically showed non-significant relationship with $\mathrm{T}_{6}(40 \%)$ concentration. $\mathrm{T}_{4} \quad(10 \%)$ concentrations statistically showed significant relationship with $\mathrm{T}_{3}$ (5\%) concentration. $\mathrm{T}_{2} \quad(2.5 \%)$ concentrations showed significant relationship with $\mathrm{T}_{7}(80 \%) . \mathrm{T}_{7}(80 \%)$ concentration showed significant relationship with control $\mathrm{T}_{1} \quad(0 \%)$ concentration. The root length of radish was significantly decreasing $(83 \%)$ at $\mathrm{T}_{7}$ $(80 \%)$ which was statically similar at $\mathrm{T}_{6}$ $(40 \%)$ concentration as compared to control $\mathrm{T}_{1}(0 \%)$ concentration. These results were similar with earlier studies and seedling growth bioassays that water extracts of allelopathic plants were more pronounced effects on radicle growth than on hypocotyl growth and might be the presence of numerous allelochemicals in the abstract solution (Rice et al., 2007). Arooj et al. (2021) directed that the atrazine produces hermetic effect at dose of $10 \mathrm{~g}$ a.i. (lower dose) while showed herbicidal at higher dose (80 $\mathrm{g}$ a.i.) and produce maximum root length (9.99) and minimum root length $(7.34 \mathrm{~cm})$ respectively.

\section{Shoot fresh weight}

The aqueous extract of
Cinnamomum verum (bark) had significant effect on shoot fresh weight of Raphanus sativus $L$. as described in Table 2. Maximum fresh weight of shoot $(16.3 \mathrm{mg})$ were noted at $\mathrm{T}_{5}(20 \%)$ concentration. Minimum fresh weight of shoot $(10.2 \mathrm{mg})$ were noted at $\mathrm{T}_{4}(10 \%)$ concentration treatment. $T_{7} \quad(80 \%)$ concentration showed non-significant relationship with $\mathrm{T}_{2}(2.5 \%)$ concentration which was statically similar with $\mathrm{T}_{3}(5 \%)$ and $\mathrm{T}_{6}(40 \%)$ concentrations. $\mathrm{T}_{5}(20 \%)$ concentration showed significant relationship with control $\mathrm{T}_{1}(0 \%)$ concentration. The fresh weight of shoot significantly increased (11\%) increased at $\mathrm{T}_{7}(80 \%)$ concentration as compared to control $\mathrm{T}_{1}(0 \%)$. The fresh weight of shoot significantly decreased $(21 \%)$ at
$\mathrm{T}_{4}(10 \%)$ concentration as compared to control $\mathrm{T}_{1}(0 \%)$ concentration. The increase in fresh weight of radish seed may be due the stimulatory allelochemicals in these extracts and shoot of radish show more resistant at higher concentration of extract. While lower concentrations of extract were suitable to reduce the fresh weight of radish. That result is not corresponding to Srivastava et al. (1996) that water abstracts of plants and inflorescences at higher concentration suppressed the germination seedling growth and reduce the fresh and dried mass of barley wheat and pea. (Arooj et al., 2021) reported that Atrazine at lower dose $(10 \mathrm{~g}$ a.i.) produce hermetic effect and gave highest fresh weight while at higher dose (80 g a.e.) produce herbicidal effect and produce minimum fresh weight of Tribulus terrestris.

\section{Root fresh weight}

The effect of $C$. verum (bark) aqueous extract had significant effect on root fresh weight of $R$. sativus as described in table (2). Maximum root fresh weight $(57.6 \mathrm{mg})$ was observed at $\mathrm{T}_{7}(80 \%)$ concentration. Minimum fresh weight of root $(30.0 \mathrm{mg})$ was noted at control $\mathrm{T}_{1}(0 \%)$. $\mathrm{T}_{7}(80 \%)$ concentration had significant relationship with control $\mathrm{T}_{1}(0 \%) . \mathrm{T}_{3}(5 \%)$ concentration had non-significant relationship with $\mathrm{T}_{4}$ $(10 \%)$ concentration which was statically at par with $\mathrm{T}_{2}(2.5 \%), \mathrm{T}_{6}(40 \%)$ and $\mathrm{T}_{1}$ $(0 \%)$ concentration. The fresh weight of root significantly increased $92 \%$ increased at $\mathrm{T}_{7}(80 \%)$ concentration as compared to control $\mathrm{T}_{1}(0 \%)$. The fresh weight of shoot significantly decreased $42 \%$ at $\mathrm{T}_{6}(80 \%)$ concentration as compared to $\mathrm{T}_{7}(80 \%)$ concentration. Highest concentration of extract not significantly reduce the root fresh weight of radish. The rise in fresh weight of radish may be due the stimulatory phytochemicals in these extract and root of radish show more resistant at higher concentration of extract. While lower concentrations of extract were suitable to reduce the fresh weight of radish. Similar results were reported by Mubeen et al. (2011) who found that leaf extract of Trianthema portulacastrum inhibited maximum reduction on shoot and root 
length of rice seedling whereas minimum shoot and root dry weight was occurred as a result of interactive effect of different weeds and their water extracts.

Phenolic compounds and their concentration in $C$. verum

Phenolic compounds and their concentration in $C$. verum were presented in Table 3. In $C$. verum quercetion, vanilic acid, pcoumeric acid, caffic acid and chlorogenic acid were detected. Among these phenolic compounds detected in $C$. verum maximum quercetin (12.3\%) compound and minimum p-coumaric aid $(0.89 \%)$ was found.

\section{Conclusion}

The results of experiment directed that aqueous extract of bark of $C$. verum showed inhibitory effect on radish germination and seedling growth at higher concentration (80\%) and growth regulatory effect at lower concentration. Among phenolic compounds detected in C. verum, maximum Quercetin $(12.3 \%)$ compound and minimum p-coumaric acid $(0.89 \%)$ were found.

Accordingly, aqueous extract of bark of C. verum can be used as potential bioherbicide to control weed at $80 \%$ concentration and growth regulator at lower concentration. Also, further studies are recommended in order to fix and support the obtained findings.

Table 1: Allelopathic effect of $C$. verum on emergence of $R$. sativus seeds

\begin{tabular}{|l|c|c|c|c|}
\hline $\begin{array}{c}\text { Concentration } \\
(\%)\end{array}$ & $\begin{array}{c}\text { Time to 50\% } \\
\text { germination (days) }\end{array}$ & $\begin{array}{c}\text { Germination } \\
\text { Index }\end{array}$ & $\begin{array}{c}\text { Mean germination } \\
\text { Time (days) }\end{array}$ & $\begin{array}{c}\text { Germination } \\
\text { (\%) }\end{array}$ \\
\hline $0 \%$ & $4.59 \mathrm{~b}$ & $6.21 \mathrm{~b}$ & $6.44 \mathrm{~b}$ & $83.3 \mathrm{~b}$ \\
\hline $2.5 \%$ & $4.56 \mathrm{~b}$ & $5.39 \mathrm{bc}$ & $5.89 \mathrm{bc}$ & $80.0 \mathrm{bc}$ \\
\hline $5 \%$ & $4.42 \mathrm{~b}$ & $6.08 \mathrm{~b}$ & $5.45 \mathrm{~cd}$ & $83.3 \mathrm{~b}$ \\
\hline $10 \%$ & $4.27 \mathrm{~b}$ & $6.14 \mathrm{~b}$ & $5.25 \mathrm{~cd}$ & $86.6 \mathrm{~b}$ \\
\hline $20 \%$ & $4.03 \mathrm{~b}$ & $8.05 \mathrm{a}$ & $4.82 \mathrm{~d}$ & $96.6 \mathrm{a}$ \\
\hline $40 \%$ & $4.58 \mathrm{~b}$ & $5.06 \mathrm{c}$ & $5.78 \mathrm{bd}$ & $70.0 \mathrm{c}$ \\
\hline $80 \%$ & $5.91 \mathrm{a}$ & $4.93 \mathrm{c}$ & $7.54 \mathrm{a}$ & $70.0 \mathrm{c}$ \\
\hline LSD & $\mathbf{0 . 7 6 6 5}$ & $\mathbf{0 . 8 6 6 2}$ & $\mathbf{1 . 0 0 2 9}$ & $\mathbf{1 0 . 1 1 1}$ \\
\hline
\end{tabular}

Table 2: Allelopathic effect of $C$. verum seedling growth on $R$. sativus seeds

\begin{tabular}{|l|c|c|c|c|}
\hline $\begin{array}{l}\text { Concentration } \\
(\%)\end{array}$ & $\begin{array}{l}\text { Shoot length } \\
(\mathbf{c m})\end{array}$ & $\begin{array}{l}\text { Root length } \\
(\mathbf{c m})\end{array}$ & $\begin{array}{l}\text { Shoot fresh } \\
\text { weight }\end{array}$ & $\begin{array}{l}\text { Root } \\
\text { weight }\end{array}$ \\
\hline $0 \%$ & $61.6 \mathrm{~d}$ & $42.4 \mathrm{~d})$ & $30.0 \mathrm{~d}$ \\
\hline $2.5 \%$ & $79.0 \mathrm{c}$ & $61.7 \mathrm{c}$ & $13.0 \mathrm{~d}$ & $33.3 \mathrm{bc}$ \\
\hline $5 \%$ & $80.6 \mathrm{bc}$ & $52.0 \mathrm{~cd}$ & $14.5 \mathrm{bc}$ & $33.3 \mathrm{c}$ \\
\hline $10 \%$ & $85.0 \mathrm{~b}$ & $86.8 \mathrm{~b}$ & $14.6 \mathrm{~b}$ & $45.3 \mathrm{~b}$ \\
\hline $20 \%$ & $93.8 \mathrm{a}$ & $129.3 \mathrm{a}$ & $16.3 \mathrm{a}$ & $57.6 \mathrm{a}$ \\
\hline $40 \%$ & $80.8 \mathrm{bc}$ & $26.6 \mathrm{e}$ & $14.0 \mathrm{c}$ & $30.6 \mathrm{~cd}$ \\
\hline $80 \%$ & $77.6 \mathrm{c}$ & $21.7 \mathrm{e}$ & $10.2 \mathrm{e}$ & $30.6 \mathrm{~cd}$ \\
\hline LSD & $\mathbf{5 . 6 2 0 3}$ & $\mathbf{1 0 . 0 2 7}$ & $\mathbf{6 . 0 9 6 7}$ & $\mathbf{3 . 0 2 7 4}$ \\
\hline
\end{tabular}

Table 3: Phenolic compounds and their concentration in A. officinalis

\begin{tabular}{|l|c|}
\hline Phenolic compounds & Concentration \\
\hline Syringic acid & 0.60 \\
\hline p-crumeic & 0.94 \\
\hline Ferulic acid & 7.48 \\
\hline Quercetion & 12.3 \\
\hline Gallic acid & 4.69 \\
\hline
\end{tabular}




\section{References}

Arooj, M., B.A. Khan, M.A. Nadeem,; M.M. Javaid, E. Rashid, M.S.J. Jlani; J. Qamar, F. Ali, S. Javaria and M. Faisal. 2021. Low doses of atrazine causes hormesis in Tribulus terrestris. Pak. J. Weed Sci. Res., 27(3): 351-358

Association of Official Seed Analysis. 1990. Rules for testing seeds. J. Seed Technol., 12: 1-112.

Bhatt, B.P. and N.P. Todoria. 1990. Studies on the allelopathic effects of some agroforestry tree crops of Garhwal Himalaya. Agro. For. Syst. 12: 251-255.

Cheema, Z. A., A. Rakha and A. Khaliq 2000a. Use of sorgaab and sorghum mulch for weed management in mungbean. Pak. J. Agric. Sci. 37: 140-144.

Cheema, Z.A., M. Asim and A. Khaliq 2000b. Sorghum allelopathy for weed control in cotton (Gossypium arboretum L.). Int. J. Agric. Biol., 2: 37-41.

Cheema, Z.A., M. Farooq and A. Khaliq. 2012. Application of allelopathy in crop production success story from Pakistan. In Allelopathy. Springer, Berlin, Heidelberg. Current Trends and Future Applications. pp. 113-143.

Cheema, Z.A., M. Luqman and A. Khaliq. 1997. Use of allelopathic extracts of sorghum and sunflower herbage for weed control in wheat. J. Anim. Plant Sci., 7: 9193.

Coolbear P., A. Francis and D. Grierson. 1984. The effect of low temperature pre-sowing treatment on the germination performance and membrane integrity of artificially aged tomato seeds. J. Exp. Bot., 35: 1609-1617.

Djurdjevic, L., A. Dinic, P. Pavlovic, M. Mitrovic, M. Karadzic and $M$. Tesevic. 2004. Alleopathic potential of Allium ursinum $\mathrm{L}$. Biochem. Syst. Ecol., 32: 533-544.

Ellis R. A. and E.H. Roberts. 1981. The quantification of aging and survival in orthodox seeds. Seed Sci. Technol. 9: 373-409.
Golisz, A., B. Lata, S.W. Gawronski and Y. Fujii. 2007. Specific and total activities of the allelochemicals identified in buckwheat. Weed Biol. Manage., 7(3): 164-171.

Hazrati, H., M.J. Saharkhiz, M. Niakousari and M. Moein. 2017. Natural herbicide activity of Satureja hortensis L. essential oil nanoemulsion on the seed germination and morphophysiological features of two important weed species. Ecotoxicol. Environ. Saf., 142: 423-430.

Jamil, M., Z.A. Cheema, M.N. Mushtaq, M. Farooq and M.A. Cheema. 2009. Alternative control of wild oat and canary grass in wheat fields by allelopathic plant water extracts. Agron. Sustain. Dev. 29: 475-482.

Javaid, A. 2010. Herbicidal potential of allelopathic plants and fungi against Parthenium hysterophorus - a review. Allelopathy J., 25(2): 331-344.

Javaid, A., S. Shafique and S. Shafique. 2010. Herbicidal effects of extracts and residue incorporation of Datura metel against parthenium weed. Nat. Prod. Res., 24(15): 1426-1437.

Javaid, A., S. Shafique, Q. Kanwal and S. Shafique. 2010a. Herbicidal activity of flavonoids of mango leaves against Parthenium hysterophorus L. Nat. Prod. Res., 24(19): 1865-1875.

Javaid, N., M.H. Shah, I.H. Khan, A. Javaid and S.M. Waleed. 2020. Herbicidal activity of Ageratum conyzoides against parthenium. Pak. J. Weed Sci. Res., 26(2): 137-146.

King, S. R. and R. Ambika. 2002. Allelopathic plants. 5. Chromola enodorata L. Allelopath. J., 9: 3541.

Kubeczka, K. H. 2002. Eessential Oils Analysis by Capillary Gas Chromatography and Carbon 13 NMR Spectroscopy. Hoboken, NJ: John Wiley and Sons.

Maqbool, R., B.A. Khan, S. Parvez, M. A. Nadeem, A. Hassan, J. Qamar, A. 
Nawaz, M. Adnan, R. khalid, M. Usman. 2021a. Exploring the allelopathic and hermetic effect of khatami (Altheae officinalis) on emergence and seedling growth of radish (Raphanus sativus). Pak. J. Weed Sci. Res., 27 (3): 321-330.

Maqbool, R., B.A. Khan, S. Parvez, M. A. Nadeem, M.M. Ud Din, M. Waqas, J. Qamar, M.M. Amin, B. Khalid. 2021b. Identifying the hermetic potential of khatami (Altheae officinalis) emergence and seedling growth of wild pea (Pisum sativum subsp. elatius). Pak. J. Weed Sci. Res., 27(3): 331-340.

Mubeen, K., M.A. Nadeem, A. Tanveer and Z.A. Zahir. 2011. Allelopathic effect of Aqueous extracts of weeds on the germination and seedling growth of rice (Oryza sativa L.). Pak. J. Life Soc. Sci., 9: 7-12.

Murrell, C., E. Gerber, C. Krebs, M. Parepa, U. Schaffner and O. Bossdorf. 2011. Invasive knotweed affects native plants through allelopathy. Am. J. Bot., 98(1): 38-43.

Nadeem, M.A., B.A. Khan, S. Afzal, A. Aziz, R. Maqbool, M.M. Amin, A. Aziz, A. Ali, M. Adnan and Durrishahwar. 2020b. Allelopathic Effects of aqueous extracts of Carthamus tinctorius L. on emergence and seedling growth of Echinochloa crus-galli L. Pak. J. Weed Sci. Res., 26(3): 365379.

Nadeem, M.A., B.A. Khan, S. Afzal, M. A. Khan, T. Abbas, M.M. Javaid, M.M. Amin, N. Farooq and A. Aziz. 2020a. Effect of aqueous extract of Carthamus tinctorius L. on germination and initial seedling growth of Oryza punctata L. Pak. J. Weed Sci. Res., 26(3): 331-342.

Nelson, C.J. 1996. Allelopathy in cropping system. Agron. J. 88: 991-996.

Reigosa, J.M. Pedrol and N.L. Gonzalez. 2006. Allelopathy: A Physiological Process with Ecological
Implication, Springer-Verlag, Germany, pp.637.

Rice, A., J. Johnson-Maynard, D. Thill and M. Morra. 2007. Vegetable crop emergence and weed control following amendment with different Brassicaceae seed meals. Renew. Agric. Food Syst. 9: 475-482.

Rice, E.L. 1984. Manipulated Ecosystems: Role of Allelopathy in Agriculture, In: Allelopathy, $2^{\text {nd }}$ Ed., Academic Press, Orlando, pp. 8-73.

Smitt, A. E. 1990. The potential allelochemical characteristics of bitter sneze weed (Helenium amarum). Weed Sci., 37: 665669.

Sodaeizadeh, H., M. Rafieiolhossaini. and P. Van Damme. 2010. Herbicidal activity of a medicinal plant, Peganum harmala L., and decomposition dynamics of its phytotoxins in the soil. Ind. Crop and Prod., 31(2): 385-394.

Srivastava, S., A.K. Tripathi and A. Jain. 1996. Phytochemical investigation of some forest tree species for their allelopathic potential. Indian J. Ecol., 23:2128.

Steel, R.G.D., J.H. Torrie and D.A. Dickey. 1997. Principles and procedures of statistics: a biometrical approach. $3^{\text {rd }}$ ed. New York: McGraw Hill Book, pp.1727.

Tigre, R.C., N.H. Silva, M.G. Santos, N.K. Honda, E.P.S. Falcao and E.C. Pereira. 2012. Allelopathic and Bioherbicidal potential of Cladonia verticillaris on the germination and growth of Lactuca sativa. Ecotoxicol. Environ. Saf., 84:125-132.

Tobe, K, Li, X. and K. Omasa. 2000. Seed germination and radicle growth of halophyte Kalidum capsicum (Chenopediaceae). Ann. Bot., 85: 391-396.

Turk, M.A. and A.M. Tawaha. 2003. Allelopathic effect of black mustard (Brassica nigra L.) on germination and growth of wild 
494 Rizwan Maqbool, Bilal Ahmad Khan et al. Allelopathic Effect of Cinnamomum ....

oat (Avena fatua L.). Crop Prot., 22: 673-677. 